\title{
Antifungal activity and mechanism of the essential oils from Litsea (Litsea cubeba), Melissa (Melissa officinalis), Palmarosa (Cymbopogon martini) and Verbena (Verbena officinalis) and their major active constituents against Trametes hirsuta and Laetiporus sulphureus
}

Yongjian Xie ( $\nabla$ yjxie@zafu.edu.cn )

Zhejiang A \& F University https://orcid.org/0000-0001-8225-7720

\section{Xi Yang}

Zhejiang A\&F University

Hui Han

Zhejiang A\&F University

Zhilin Zhang

Hubei Engineering University

Dayu Zhang

Zhejiang A\&F University

Research Article

Keywords: Antifungal activity, Essential oils, Litsea cubeba, Geranial, Membrane damage

Posted Date: August 13th, 2021

DOl: https://doi.org/10.21203/rs.3.rs-680348/v1

License: (a) (i) This work is licensed under a Creative Commons Attribution 4.0 International License.

Read Full License 


\section{Abstract}

Antifungal activities of 37 essential oils (EOs) against two wood-decaying fungi, Trametes hirsuta and Laetiporus sulphureus were screened in vitro, and investigated the underlying mechanism. Of the $37 \mathrm{EOs,}$ litsea (Litsea cubeba), melissa (Melissa officinalis), palmarosa (Cymbopogon martini), and verbena (Verbena officinalis) demonstrated strong antifungal activity, in which litsea oil exhibited the strongest antifungal property against $T$. hirsuta and $L$. sulphureus, with $\mathrm{IC}_{50}$ values of 72.3 and $40.2 \mu \mathrm{g} / \mathrm{ml}$, respectively. The compositions of litsea, melissa, palmarosa, and verbena EOs were analyzed using a gas chromatography-mass spectrometry method and demonstrated geranial, geraniol, neral, and citral as their major active constituents. Among of them geranial exhibited the strongest antifungal activity against $T$. hirsuta and $L$. sulphureus, with $\mathrm{IC}_{50}$ values of 56.6 and $33.3 \mu \mathrm{g} / \mathrm{ml}$, respectively. These EOs and their major active constituents increased the plasma membrane permeability of $T$. hirsuta and $L$. sulphureus, resulting in the leakage of nucleic acid, protein, and soluble sugar. Results indicate that the EOs of litsea, melissa, palmarosa, and verbena and its major constituents inhibited $T$. hirsuta and $L$. sulphureus growth by targeting its plasma membrane.

\section{Introduction}

The biodegradation of lignocellulosic materials occurs by beetles, fungi, marine borers, and termites; among these, fungi are recognized to cause the greatest financial loss of wooden products (Wu et al. 2012). Decay fungi, molds, and stain fungi are universally recognized as major wood-degradation fungi (Bakar et al. 2013). In general, traditional wood preservatives are ammoniacal copper quaternary (ACQ), chromated copper arsenates (CCAs), copper azole (CA), and copper (II) dimethyldithiocarbamate (CDDC), which significantly affect human health and the environment (Chen et al. 2014). Therefore, there is an urgent need to research and explore more eco-friendly, convenient, and highly effective benign wood preservatives for lignocellulosic materials.

In recent years, many natural plant products that are non-residual, biodegradable, and environmentally friendly have been shown to be excellent potential alternatives for preserving the wood industry (Xie et al. 2017a). Studies have shown that plant essential oils (EOs) from Calocedrus fromosana, Cryptomeria japonica, Cinnamomum osmophloem, Ci. zeylanicum, Cymbopogon citratus, Cunninghamia konishii, Eucalyptus camaldulensis, Eugenia caryophyllata, Machilus philippinensis, Origanum vulgare, Pelargonium graveolens, and Thymus vulgaris have antifungal properties (Cheng et al. 2005, 2006, 2011; Ho et al. 2010; Xie et al. 2015, 2017a; Salem et al. 2016). As is well known, the strong antifungal activity of EOs against wood decaying fungi were contributed to a rich of monoterpenes, sesquiterpenes and phenylpropanoids (Cheng et al. 2012; Zhang et al. 2016a). Most EOs and their compounds destroy the integrity of fungal cell membranes, resulted in the outflow of intracellular components and cell death (Kalily et al. 2016; Zhang et al. 2016b; Zhou et al. 2017; Souza et al. 2020; Yan et al. 2020).

Research on EOs as biological agents for protecting wood and prolonging their application life and as an alternative to chemical wood preservatives is becoming increasingly a necessity. For this reason, this 
study examined the antifungal activity of 37 EOs against wood-decay fungi. We also analyzed the chemical composition of EOs with the strongest antifungal activity by gas chromatography-mass spectrometry. In addition, we evaluated the antifungal activity of the major active constituents in the selected EOs and elucidated the relationship between the active constituents and their antifungal properties. Finally, we investigated the changes in plasma membrane permeability of $T$. hirsuta and $L$. sulphureus caused by selected EOs.

\section{Materials And Methods 2.1. Wood decay fungi}

Trametes hirsuta (CFCC 84683) and Laetiporus sulphureus (CFCC 86368) were procured from China Forestry Culture Collection Center.

\subsection{Essential oils and chemicals}

The antifungal activities of 37 EOs against wood rot fungi in vitro were screened (Table 1). Litsea cubeba and Verbena officinalis were procured from Rihua Chemical Co. Ltd. (Guangzhou, China). The other EOs was purchased from Huien International Business Co. Ltd. (Shanghai, China). Geraniol, neral, citral, and geranial were purchased from Sigma-Aldrich (China). 
Table 1

List of plant essential oils tested for wood-decay fungi

\begin{tabular}{|c|c|c|c|c|}
\hline oil & source of plant & family name & part & origin \\
\hline Chamomile & Anthemis nobilis & Compositae & Flower & France \\
\hline Wormwood & Artemisia argyi & Compositae & Leaves & China \\
\hline Cypress & Cupressus sempervirens & Cupressaceae & Leaves & France \\
\hline Juniper berry & Juniperus communis & Cupressaceae & Fruit & France \\
\hline Palmarosa & Cymbopogon martini & Gramineae & Leaves & Brazil \\
\hline Citronella & Cymbopogon winterianus & Gramineae & Leaves & Java \\
\hline Vetiver & Vetiveria zizanoides & Gramineae & Root & India \\
\hline Lavender & Lavandula angustifolia & Lamiaceae & Leaves & France \\
\hline Melissa & Melissa officinalis & Lamiaceae & Leaves & France \\
\hline Peppermint & Mentha arvensis & Lamiaceae & Leaves & America \\
\hline Basil & Ocimum basilicum & Lamiaceae & Leaves & Italy \\
\hline Marjoram & Origanum majorana & Lamiaceae & Flower & Egypt \\
\hline Patchouli & Pogostemon cablin & Lamiaceae & Leaves & Malaysia \\
\hline Rosemary & Rosmarinus officinalis & Lamiaceae & Leaves & Morocco \\
\hline Clary sage & Salvia sclarea & Lamiaceae & Leaves & Russia \\
\hline Litsea & Litsea cubeba & Lauraceae & Fruit & China \\
\hline Ravensara & Ravensara aromatic & Lauraceae & Leaves & Madagascar \\
\hline Eucalypyus & Eucalyptus globulus & Myrtaceae & Leaves & Australia \\
\hline Tea tree & Melaleuca alternifolia & Myrtaceae & Leaves & Australia \\
\hline Cajeput & Melaleuca leucadendra & Myrtaceae & Leaves & Australia \\
\hline Niaouli & Melaleuca viridiflora & Myrtaceae & Leaves & Australia \\
\hline Cedarwood & Cedrus atlantica & Pinaceae & Bark & America \\
\hline Lignum cedrium & Cedrus deodara & Pinaceae & Heart wood & America \\
\hline Black pepper & Piper nigrum & Piperaceae & Fruit & India \\
\hline Bergamot & Citrus aurantium bergamia & Rutaceae & Peel & Italy \\
\hline Neroli & Citrus aurantium amara & Rutaceae & Flower & Egypt \\
\hline Orange & Citrus aurantium dulcis & Rutaceae & Peel & Italy \\
\hline Grapefruit & Citrus grandis & Rutaceae & Peel & Italy \\
\hline
\end{tabular}




\begin{tabular}{|c|c|c|c|c|}
\hline oil & source of plant & family name & part & origin \\
\hline Lemon & Citrus limon & Rutaceae & Peel & Italy \\
\hline Mandarin & Citrus reticulate & Rutaceae & Peel & Italy \\
\hline Dill Seed & Anethum graveolens & Umbelliferae & Seed & China \\
\hline Coriander & Coriandrum sativum & Umbelliferae & Fruit & China \\
\hline Caraway & Carum carvi & Umbelliferae & Seed & China \\
\hline Fennel & Foeniculum vulgre & Umbelliferae & Seeds & Hungary \\
\hline Chuanqiong & Ligusticum chuanxiong & Umbelliferae & Root & China \\
\hline Verbena & Verbena officinalis & Verbenaceaex & Leaves & Spain \\
\hline Ginger & Zingiber officinale & Zingiberaceae & Stem & China \\
\hline
\end{tabular}

\subsection{GC-MS}

The chemical analysis of EOs compounds was determined by GC-MS using an Agilent 6890A/5975C, equipped with a HP-5 capillary column. Analytical conditions were as follows: The GC oven temperature was set at $50^{\circ} \mathrm{C}$ for $10 \mathrm{~min}$, and raised to $280^{\circ} \mathrm{C}$ at $10^{\circ} \mathrm{C} / \mathrm{min}$; He was the carrier gas at $1.0 \mathrm{ml} / \mathrm{min}$; the injection of $1.0 \mu \mathrm{l}$; and split ratio of 1:50. The chemical components were identified by NIST mass spectrometry Library (NIST 11.0) and retention index (RI). The relative indices were determined in relation to the series of n-alkanes, with respect to those reported in the literature (Adams, 2007).

\subsection{Antifungal assay}

The antifungal activity of EOs and active compounds were examined using an in vitro assay by Xie et al. (2017a). Briefly, $25-400 \mu \mathrm{g} / \mathrm{ml}$ of EOs or their major constituent were added to $20 \mathrm{ml}$ sterilize PDA medium and poured into in $9 \mathrm{~cm}$ petri dishes, then inoculation mycelial disc $(5 \mathrm{~mm})$ were pace in the center of each dish and incubated at $26 \pm 1^{\circ} \mathrm{C}$ for $5-7$ days. Three replicates were done for each dose. When the mycelia reached the edge of control plates (only distilled water), antifungal indices were calculated.

\subsection{Membrane integrity determination}

\subsubsection{Effect of EOs on fungal membrane integrity with propidium iodide $(\mathrm{PI})$ dyeing}

Membrane integrity of T. hirsuta and L. sulphureus was determined following Yan et al. (2020) method with a confocal laser scanning microscope (CLSM). The fungi were incubated for $24 \mathrm{~h}$ in PDB containing the four EOs and its major constituents $(1 \mu \mathrm{l} / \mathrm{ml})$, respectively, and then collected mycelia and stained with PI $(1 \mu \mathrm{g} / \mathrm{ml})$ for $30 \mathrm{~min}$ at $28^{\circ} \mathrm{C}$ in dark. After staining, the mycelia were washed three times with the phosphate buffered saline (PBS, PH 7.4) to remove residual dye. Then use CLSM (Zeiss LSM880, 
Germany) to observe PI with excitation/emission wavelengths $561 \mathrm{~nm} / 591$ to $635 \mathrm{~nm}$. Each experiment was repeated three times.

\subsubsection{Effect of EOs on leakage of fungal nucleic acid and protein}

Fungal nucleic acid and protein leakage were measured according to the methods of Shao et al. (2013) with slight modifications. Fungi were incubated for $24 \mathrm{~h}$ in PDB with four EOs or their major constituent (1 $\mu \mathrm{l} / \mathrm{ml}$ ), then supernatant was used for nucleic acid and protein leakage determination, which was quantified using NanoDrop ONE (Thermo SCIENTIFIC). The experiment was performed in three replicates each.

\subsubsection{Effect of EOs on fungal soluble sugar content}

Soluble sugar content was measured according to the anthrone-sulfuric acid method by Smith et al. (1985), with slight modifications. $800 \mu \mathrm{l}$ of filtrates and $100 \mu \mathrm{l}$ of anthrone-ethyl acetate were mixed, then $1 \mathrm{ml}$ of $\mathrm{H}_{2} \mathrm{SO}_{4}$ was added and incubated at $95^{\circ} \mathrm{C}$ for $10 \mathrm{~min}$, and cooled down at room temperature. Finally, the absorbance was recorded at $620 \mathrm{~nm}$.

\subsection{Statistical analyses}

The experiments were performed in three replicates, and the experimental results were obtained from mean \pm SD. The data of inhibition rate was analyzed using one-way ANOVA by Duncan's test $(p<0.05)$.

\section{Results}

\subsection{Antifungal activity of the EOs}

The antifungal activity of 37 plant EOs against two wood-decay fungi (Table 2), of these, 4 EOs, litsea (Litsea cubeba), melissa (Melissa officinalis), palmarosa (Cymbopogon martini), and verbena (Verbena officinalis), achieved $100 \%$ inhibition of $T$. hirsuta and L. sulphureus at $400 \mu \mathrm{g} / \mathrm{ml}$. The litsea and verbena EOs showed $100 \%$ antifungal activity when the concentration was decreased to $200 \mu \mathrm{g} / \mathrm{ml}$ (Fig. 1A-D). 
Table 2

Antifungal activities of essential oils against white-rot fungs T. hirsuta and brown-rot fungs $L$. sulphureus

\begin{tabular}{|c|c|c|}
\hline \multirow[t]{2}{*}{ Plant species } & \multicolumn{2}{|c|}{ Inhibition $(\%$, mean \pm SD) } \\
\hline & T. hirsuta & L. sulphureus \\
\hline Chamomile & $62.2 \pm 1.3 \mathrm{bc}$ & $77.0 \pm 1.6 b$ \\
\hline Wormwood & $4.1 \pm 2.0 \mathrm{jk}$ & $8.1 \pm 1.0 \mathrm{jk}$ \\
\hline Cypress & $21.5 \pm 1.5$ fghij & $23.3 \pm 1.3 \mathrm{fghij}$ \\
\hline Juniper berry & $25.6 \pm 1.3 \mathrm{fghi}$ & $26.3 \pm 0.4$ fghij \\
\hline Palmarosa & $100 \mathrm{a}$ & $100 \mathrm{a}$ \\
\hline Citronella & $51.5 \pm 1.6 \mathrm{~cd}$ & $75.2 \pm 2.6 b$ \\
\hline Vetiver & $76.7 \pm 2.8 b$ & $83.0 \pm 1.3 \mathrm{ab}$ \\
\hline Lavender & $0 \mathrm{k}$ & $21.1 \pm 2.3$ ghij \\
\hline Melissa & $100 \mathrm{a}$ & $100 \mathrm{a}$ \\
\hline Peppermint & $23.0 \pm 2.0$ fghij & $42.2 \pm 3.4 \mathrm{def}$ \\
\hline Basil & $64.8 \pm 1.3 \mathrm{bc}$ & $100 \mathrm{a}$ \\
\hline Marjoram & $28.5 \pm 8.1$ efghi & $19.6 \pm 0.7$ ghij \\
\hline Patchouli & $68.9 \pm 2.3 \mathrm{bc}$ & $83.3 \pm 2.3 \mathrm{ab}$ \\
\hline Rosemary & $23.0 \pm 2.0 \mathrm{fghij}$ & $34.4 \pm 1.3$ efg \\
\hline Clary sage & $26.3 \pm 1.6 \mathrm{fghi}$ & $23.7 \pm 1.6$ fghij \\
\hline Litsea & $100 \mathrm{a}$ & $100 \mathrm{a}$ \\
\hline Ravensara & $38.1 \pm 1.0$ def & $18.1 \pm 1.6$ ghijk \\
\hline Eucalypyus & $14.1 \pm 2.3 \mathrm{hijk}$ & $0 \mathrm{k}$ \\
\hline Tea tree & $15.2 \pm 1.6$ ghijk & $10.0 \pm 2.2 \mathrm{jk}$ \\
\hline Cajeput & $15.2 \pm 1.6$ ghijk & $18.1 \pm 3.5$ ghijk \\
\hline Niaouli & $25.9 \pm 0.7 \mathrm{fghi}$ & $26.3 \pm 2.6 \mathrm{fghij}$ \\
\hline Cedarwood & $34.4 \pm 1.3$ defgh & $37.4 \pm 1.6$ defg \\
\hline Lignum cedrium & $26.7 \pm 1.7 \mathrm{fghi}$ & $13.0 \pm 1.6$ hijk \\
\hline Black pepper & $26.7 \pm 1.3 \mathrm{fghi}$ & $53.7 \pm 3.2 \mathrm{cde}$ \\
\hline Bergamot & $0 \mathrm{k}$ & $26.0 \pm 1.6 \mathrm{fghij}$ \\
\hline
\end{tabular}




\begin{tabular}{|lll|}
\hline Plant species & \multicolumn{2}{l|}{ Inhibition (\%, mean \pm SD) } \\
\cline { 2 - 3 } Neroli & T. hirsuta & L. sulphureus \\
Orange & $17.0 \pm 2.0 \mathrm{fghijk}$ & $31.9 \pm 1.6 \mathrm{fgh}$ \\
Grapefruit & $0 \mathrm{k}$ & $11.9 \pm 2.3 \mathrm{ijk}$ \\
Lemon & $0 \mathrm{k}$ & $0 \mathrm{k}$ \\
Mandarin & $0 \mathrm{k}$ & $18.1 \pm 1.3 \mathrm{ghijk}$ \\
Dill Seed & $13.0 \pm 1.3 \mathrm{ijk}$ & $7.8 \pm 0.6 \mathrm{jk}$ \\
Coriander & $29.3 \pm 2.7 \mathrm{efghi}$ & $30.0 \pm 2.3 \mathrm{fghi}$ \\
Caraway & $49.6 \pm 1.3 \mathrm{cde}$ & $53.7 \pm 3.2 \mathrm{cde}$ \\
Fennel & $60.7 \pm 1.3 \mathrm{bc}$ & $100 \mathrm{a}$ \\
Chuanqiong & $55.6 \pm 1.7 \mathrm{bcd}$ & $71.1 \pm 1.9 \mathrm{bc}$ \\
Verbena & $35.9 \pm 2.1 \mathrm{defg}$ & $54.4 \pm 1.3 \mathrm{~cd}$ \\
Ginger & $100 \mathrm{a}$ & $100 \mathrm{a}$ \\
\hline $\begin{array}{l}\text { d00 } \mu \mathrm{mg} / \mathrm{ml} \text { was treated; Means within a column followed by the same letters are not significantly } \\
\text { different }(P<0.05, \text { Duncan's test). }\end{array}$ & \\
\hline
\end{tabular}

The antifungal activity of 4 EOs against two wood-decay fungi was given in Table 3 . The $\mathrm{IC}_{50}$ values of litsea, verbena, palmarosa, and melissa on T. hirsuta were $72.3,79.8,154.1$, and $156.3 \mu \mathrm{g} / \mathrm{ml}$, respectively. In addition, their $\mathrm{IC}_{50}$ values of against $L$. sulphureus were $40.2,59.0,142.0$, and $143.2 \mu \mathrm{g} / \mathrm{ml}$ (Table 3), respectively. 
Table 3

$I_{50}$ values $(\mu \mathrm{g} / \mathrm{ml})$ of the essential oils and major component against wood-rot fungus $T$. hirsuta and $L$. sulphureus

\begin{tabular}{|c|c|c|c|c|}
\hline \multirow[t]{2}{*}{ Essential oils } & \multicolumn{2}{|l|}{ T. hirsuta } & \multicolumn{2}{|l|}{ L. sulphureus } \\
\hline & $\mathrm{IC}_{50}\left(\mathrm{Cl}_{95}\right)^{\mathrm{a}}$ & $x^{2 b}$ & $\mathrm{IC}_{50}\left(\mathrm{Cl}_{95}\right)$ & $\chi^{2}$ \\
\hline litsea & $72.3(60.1-87.3)$ & 3.549 & $40.2(28.7-51.6)$ & 2.914 \\
\hline melissa & $156.3(127.3-196.5)$ & 9.953 & $143.2(116.8-178.7)$ & 6.856 \\
\hline palmarosa & $154.1(126.0-192.5)$ & 8.704 & $142.0(117.2-174.2)$ & 5.597 \\
\hline verbena & $79.8(67.1-95.3)$ & 3.471 & $59.0(46.5-73.6)$ & 5.656 \\
\hline geranial & $56.6(44.8-70.0)$ & 3.954 & $33.3(21.5-44.0)$ & 2.554 \\
\hline geraniol & $99.2(77.4-128.2)$ & 5.728 & $64.0(50.4-80.0)$ & 8.840 \\
\hline neral & $66.3(53.6-81.6)$ & 5.077 & $40.6(29.0-52.1)$ & 2.885 \\
\hline citral & $57.7(45.3-71.9)$ & 5.062 & $40.0(28.6-51.2)$ & 3.013 \\
\hline \multicolumn{5}{|c|}{$\begin{array}{l}\text { a Value in } \mu \mathrm{g} / \mathrm{ml} \text { and } \mathrm{Cl}_{95}-95 \% \text { confidence intervals, compounds activity is considered significantly } \\
\text { different when the } 95 \% \mathrm{Cl} \text { fail to overlap. }\end{array}$} \\
\hline
\end{tabular}

\subsection{Chemical compositions of the EOs}

The chemical compositions of litsea, melissa, palmarosa, and verbena EOs were shown in Table 4. The major constituents of litsea oil were geranial (32.12\%), neral (29.43\%), limonene (16.99\%), linalool $(2.18 \%)$, and myrcene $(2.17 \%)$. The main components in melissa oil were geraniol (31.0\%), followed by citronellal (20.84\%), citronellol (12.87\%), elemol (6.22\%), and $\beta$-elemene (3.99\%). Geraniol (77.42\%) was the most abundant, followed by geranyl acetate (12.29\%), linalool (3.36\%), caryophyllene $(2.07 \%)$, and nerol $(2.02 \%)$, in palmarosa oil. The rich component in verbena oil was citral $(42.57 \%)$, followed by neral (37.32\%), geranyl acetate (3.54\%), geraniol (3.41\%), and linalool (1.37\%). 
Table 4

Chemical composition of the 4 essential oils assayed for fungicidal activity

\begin{tabular}{|c|c|c|c|c|c|c|c|}
\hline No & Components & $\mathbf{R}^{\mathbf{a}}$ & LIT RI ${ }^{b}$ & litsea & melissa & palmarosa & verbena \\
\hline 1 & a-Pinene & 939 & 932 & 1.97 & 3.78 & 0.59 & 1.10 \\
\hline 2 & Camphene & 954 & 946 & 0.47 & 1.11 & 3.36 & 0.22 \\
\hline 3 & $\beta$-Pinene & 979 & 974 & 1.35 & 1.09 & 2.02 & 0.96 \\
\hline 4 & Myrcene & 991 & 988 & 2.17 & 20.84 & 77.42 & 1.37 \\
\hline 5 & 3-Carene & 1013 & 1008 & 16.99 & 12.87 & 0.58 & 0.43 \\
\hline 6 & Limonene & 1027 & 1024 & 0.56 & 0.33 & 1.23 & 0.55 \\
\hline 7 & $\beta$-Phellandrene & 1028 & 1025 & 2.18 & 31.00 & 12.29 & 0.52 \\
\hline 8 & 1,8-Cineole & 1034 & 1026 & 1.74 & 3.46 & 0.44 & 37.32 \\
\hline 9 & $\beta$-Ocimene & 1038 & 1032 & 0.68 & 0.81 & 2.07 & 3.41 \\
\hline 10 & Linalool & 1097 & 1095 & 1.03 & 3.88 & 100 & 42.57 \\
\hline 11 & Isopulegol & 1141 & 1144 & 0.69 & 1.66 & 0.59 & 3.54 \\
\hline 12 & Citronellal & 1154 & 1148 & 1.58 & 3.99 & 97.34 & 0.13 \\
\hline 13 & Terpinen-4-ol & 1177 & 1174 & 29.43 & 1.03 & 2.07 & 0.77 \\
\hline 14 & a-Terpineol & 1191 & 1186 & 0.90 & 0.50 & & 0.10 \\
\hline 15 & Nerol & 1228 & 1227 & 0.20 & 2.28 & & 0.18 \\
\hline 16 & Citronellol & 1233 & 1223 & 32.12 & 1.32 & & 0.29 \\
\hline 17 & Pulegone & 1235 & 1233 & 0.25 & 3.84 & & 93.46 \\
\hline 18 & Neral & 1240 & 1235 & 0.23 & 6.22 & & 1.32 \\
\hline 19 & Geraniol & 1250 & 1249 & 1.11 & 100 & & 90.8 \\
\hline 20 & Anethole & 1254 & 1254 & 0.11 & 3.78 & & 1.05 \\
\hline 21 & Geranial & 1272 & 1264 & 0.25 & 77.05 & & 0.29 \\
\hline 22 & Citronellyl formate & 1277 & 1271 & 96.01 & 12.96 & & \\
\hline 23 & Citral & 1316 & 1302 & 23.51 & 6.22 & & \\
\hline 24 & a-Cubebene & 1345 & 1345 & 70.55 & & & \\
\hline 25 & Geranyl acetate & 1352 & 1350 & 1.70 & & & \\
\hline
\end{tabular}




\begin{tabular}{|c|c|c|c|c|c|c|}
\hline No & Components & $\mathrm{RI}^{\mathrm{a}}$ & LIT RI & litsea & palmarosa & verbena \\
\hline 26 & Eugenol & 1356 & 1355 & & & \\
\hline 27 & Neryl acetate & 1365 & 1359 & & & \\
\hline 28 & $\beta$-Elemene & 1391 & 1389 & & & \\
\hline 29 & Caryophyllene & 1419 & 1417 & & & \\
\hline 30 & a-Humulene & 1455 & 1452 & & & \\
\hline 31 & a-Amorphene & 1473 & 1483 & & & \\
\hline 32 & Y-Muurolene & 1480 & 1476 & & & \\
\hline 33 & Germacrene D & 1485 & 1484 & & & \\
\hline 34 & a-Muurolene & 1500 & 1500 & & & \\
\hline 35 & $\delta$-Cadinene & 1523 & 1522 & & & \\
\hline 36 & Elemol & 1549 & 1548 & & & \\
\hline \multirow[t]{6}{*}{37} & Caryophyllene oxide & 1587 & 1582 & & & \\
\hline & Total identified (\%) & & & & & \\
\hline & Monoterpene hydrocarbons & & & & & \\
\hline & Oxygenated monoterpenes & & & & & \\
\hline & Sesquiterpene hydrocarbons & & & & & \\
\hline & Oxygenated sesquiterpenes & & & & & \\
\hline $\begin{array}{l}a^{a} \mathrm{Rl}, \\
\mathrm{n} \text {-all }\end{array}$ & $\begin{array}{l}\text { near retention indices on } \mathrm{HP}-5 \mathrm{I} \\
\text { nes. }\end{array}$ & $S$ colur & , experi & entally c & ermined using homolog & series of \\
\hline
\end{tabular}

\subsection{Antifungal activity of the major constituents}

To further research the relationship between EOs and it major constituents and antifungal activity, geranial, geraniol, neral, and citral, which were the major constituents of the litsea, melissa, palmarosa, and verbena EO, respectively, were selected for this study. Figure 2 showed geranial, geraniol, neral, and citral completely inhibited T. hirsuta growth at $400 \mu \mathrm{g} / \mathrm{ml}$. When the concentration was decreased to 200 $\mu \mathrm{g} / \mathrm{ml}$, geranial, neral, and citral caused complete inhibition (Fig. 2). When the concentration of the constituent was $200 \mu \mathrm{g} / \mathrm{ml}$, geranial, geraniol, neral, and citral completely inhibited the growth of $L$. sulphureus (Fig. 2).

As shown in Table 3, geranial and citral exhibited the best antifungal activities against $T$. hirsuta, with $\mathrm{IC}_{50}$ values of 56.6 and $57.7 \mu \mathrm{g} / \mathrm{ml}$, respectively. In addition, the $\mathrm{IC}_{50}$ values of geranial, citral, neral, and 
geraniol against $L$. sulphureus were $33.3,40.0,40.6$, and $64.0 \mu \mathrm{g} / \mathrm{ml}$, respectively (Table 3).

3.4 Membrane integrity of T. hirsuta and L. sulphureus exposed to 4 EOs and their major constituents

PI can detect the membrane permeability, which enters the damaged plasma membranes and combines with nucleic acids to produce red fluorescence. PI staining was used to determine whether four EOs (litsea, melissa, palmarosa, and verbena) and their major constituents (geranial, geraniol, neral, and citral, respectively) led to damage of membrane permeability in T. hirsuta and L. sulphureus. Four EOs and their major constituents were used to treat mycelium and stained by $\mathrm{PI}$, however, the control mycelium were not stained (Fig. 3A, B), indicating a considerable destruction in membrane integrity.

To confirm that the four tested EOs and their major constituents could disrupt the cell membrane integrity of $T$. hirsuta and $L$. sulphureus, the leakage of intracellular content was determined. The results are represented in Fig. 4, after being treated with the four EOs and major constituents $(1 \mu \mathrm{l} / \mathrm{ml})$ for $24 \mathrm{~h}$, the nucleotides, proteins, and soluble sugars in suspensions of $T$. hirsuta and $L$. sulphureus were released in a superior significantly quantity than that in the control mycelia. Exposure to litsea, melissa, palmarosa, and verbena EOs, the release of nucleotides, proteins, and soluble sugars significantly increased (Fig. 4AC), with litsea exhibiting the strongest impact. Similar results were obtained for the major constituents, geranial, geraniol, neral, and citral for the leakage of cellular components (Fig. 4A-C), with geranial exhibiting the strongest impact. In addition, the four EOs and their major constituents caused leakage of nucleotides, proteins, and soluble sugars in L. sulphureus than T. hirsuta.

\section{Discussion}

It is generally known that the fungicidal, insecticidal, and nematocidal activities of plant EOs can be attributed to various compounds, notably alcohols, aldehydes, phenol, terpenes, and terpenoids (Boulogne et al. 2012; Tak and Isman 2017; Benelli et al. 2018; Liu et al. 2019; Gong and Ren 2020). In previous studies, the chemical analysis of litsea, melissa, palmarosa, and verbena has been reported (Seo et al. 2009; De Martino et al. 2011; Si et al. 2012; Kakaraparthi et al. 2015; Rehman et al. 2017; Khalili et al. 2018; Kittler et al. 2018a,b; Pouyanfar et al. 2018). Comparisons between previous results revealed differences in the ratios of major and minor constituents. Xie et al. (2012) and Kakaraparthi et al. (2015) found that the chemical composition of EOs differ widely with genotype, cultivation and production conditions, environment factors, and extraction methods.

In this study, litsea, melissa, palmarosa, and verbena EOs had excellent antifungal activity against woodrotting fungi, which had not been reported previously. In our previous study we had showed that, $C$. citratus, $C$. zeylanicum, and $O$. vulgare EOs had good antifungal activity against $T$. hirsuta $\left(\mathrm{IC}_{50}=79.1-\right.$ $96.9 \mu \mathrm{g} / \mathrm{ml}$ ) and $L$. sulphureus $\left(\mathrm{IC}_{50}=36.9-69.2 \mu \mathrm{g} / \mathrm{ml}\right.$ ) (Xie et al. 2017a). Similarly, Cryptomeria japonica heartwood EO $\left(\mathrm{IC}_{50}, 39 \mu \mathrm{g} / \mathrm{ml}\right)$ and $C$. japonica sapwood $\left(\mathrm{IC}_{50}, 94 \mu \mathrm{g} / \mathrm{ml}\right)$ exhibited to have far more strong antifungal effect against $L$. sulphureus (Cheng et al. 2005). In another investigation, Wang et al. (2005) and Cheng et al. (2006) demonstrated that the growth was completely inhibited by $200 \mu \mathrm{g} / \mathrm{ml}$ 
C. osmophloeum EO against L. sulphureus. On the other hand, the extract of C. konishii $\left(\mathrm{IC}_{50}, 62 \mu \mathrm{g} / \mathrm{ml}\right)$ showed excellent antifungal activity (Cheng et al. 2012). These results demonstrated that litsea, melissa, palmarosa, and verbena EOs have excellent antifungal activity.

To evaluate the relationship between the main constituents and antifungal activity, 4 major constituents of these 4 EOs were selected and tested their antifungal activity. In our study, geranial, geraniol, neral, and citral, which were the main constituents of litsea, melissa, palmarosa, and verbena EOs, respectively, exhibited excellent antifungal activity. Similar results showed that eugenol is the major agent responsible for the strong antifungal activity of clove oil (Cheng et al. 2008; Komala et al. 2012; Matan et al. 2014; Xie et al. 2017a). In addition, our previous studies showed that six EOs exhibited antifungal activity, which contributed to their major constituent (Xie et al. 2017a). Similarly, in previous studies, Carum capticum oil exhibited strong toxicity contributed by thymol (Singh et al. 2004; Park et al. 2007). These results demonstrate that EOs have excellent antifungal activity contributed by their major constituents.

The structure-activity relationships (SARs) of EO monoterpenoids against fungi have been well studied (Zhang et al. 2016a; Xie et al. 2017a, b). The SAR of monoterpenoids and antifungal activity against decay fungi was investigated by Xie et al. (2017a). They found that aldehyde compounds (cinnamaldehyde and citral) generally had more antifungal activity to wood-decay fungi than alcohols (citronellol). In our study, aldehyde compounds (neral, citral, and geranial) exhibited stronger antifungal activity than the alcohol compound (geraniol). Similarly, Zhang et al. (2016a) reported that the aldehyde compound (citral) demonstrated higher activity than alcohol compounds ( $\beta$-citronellol, geraniol, and 3, 7dimethyl-1-octanol) against wood-decay fungi. These results demonstrated that $a, \beta$-unsaturated carbonyl compounds (neral, citral, and geranial) had a stronger active antifungal effect. Moreover, previous studies reported that aldehydes exhibited the strongest antitermitic activity (Xie et al. 2014). In another investigation, $a, \beta$-unsaturated carbonyl compounds were important in insecticidal, fungicidal, and nematocidal activities (Kim et al. 2008; Lee et al. 2008; Seo et al. 2009). This might indicate that the double bond at the $a, \beta$ position in carbonyl compounds enhances insecticidal, fungicidal, and nematocidal activities.

In this study, the litsea, melissa, palmarosa, and verbena EOs and their major constituents (geranial, geraniol, neral, and citral) had excellent antifungal activity against the two tested fungi. In addition, some researchers have found that these oils and their major constituents have excellent termiticidal properties. Seo et al. (2009) reported that litsea EO had fumigant antitermitic activity against the Japanese termite (Reticulitermes speratus). Similarly, the EO from palmarosa exhibited good antitermitic activity against Nasutitermes corniger (Lima et al. 2013). In our previous study, citral and geraniol exhibited excellent antitermitic activity (Xie et al. 2014). Similarly, geranial, geraniol, and neral also have been demonstrated excellent termiticidal activity (Seo et al. 2009). Therefore, litsea, melissa, palmarosa, and verbena EOs and their major constituents, geranial, geraniol, neral, and citral, respectively, have promising potential as eco-friendly preservatives. 
Cell membrane permeability is critical to the survival of fungal cells, where the damage of membrane could lead to the outflow of intracellular constituents to result in their death (Zhou et al. 2017; Souza et al. 2020; Yan et al. 2020). In this study, the effects of litsea, melissa, palmarosa, and verbena EOs on the integrity of mycelium membranes of T. hirsuta and L. sulphureus were observed by confocal microscopy. The PI staining results demonstrated that litsea, melissa, palmarosa, and verbena EOs disrupted the membrane integrity, with litsea having the highest effect. Similar results have been previously reported for Fusarium solani conidia treated with Aniba canelilla and Aniba parviflora EOs, indicating damage to the conidia's cytoplasmic membrane (Souza et al. 2020). Yan et al. (2020) also demonstrated that Mentha spicata, M. piperita, and Thymus vulgaris (CT carvacrol and CT thymol) EOs inhibited Rhizopus stolonifer growth by destroying the permeability of the cell membrane. In general, EO had an effective antifungal activity attributed to its major constituent (Xie et al. 2017a). This study found that geranial, geraniol, neral, and citral disrupted the cell membrane integrity of $T$. hirsuta and $L$. sulphureus hyphae. Similarly, Tian et al. (2015), Yun and Lee (2017), and Li et al. (2018) reported that ethyl p-coumarate, perillaldehyde, and silymarin had high antifungal activity, which can be attributed to their destruction of the permeability of the fungal plasma membrane. Kalily et al. (2016) demonstrated that linaool destroyed the permeability of the cell membrane, resulting in leakage of intracellular components and cell death. Zhang et al. (2016b) and Zhou et al. (2017) also reported that carvacrol, cinnamaldehyde, and eugenol could disrupt the plasma membrane of Escherichia coli and $R$. stolonifera, inducing the intracellular contents leakage.

In this study, litsea, melissa, palmarosa, and verbena EOs and their major constituents, geranial, geraniol neral, and citral, respectively, resulted in the leakage of cytoplasmic contents of nuclei acids, proteins, and sugars increased significantly, indicating the breakdown of plasma membrane structures and function. This is consistent with PI staining results. Similarly, Souza et al. (2020) and Yan et al. (2020) showed that A. canelilla, A. parviflora, and $T$. vulgaris EOs damaged the plasma membrane of $R$. stolonifer and $F$. solani and resulted in the leakage of intercellular electrolyte. Zhou et al. (2017) also demonstrated that carvacrol and eugenol could result in the damage of membrane permeability, causing the outflow of cytoplasm, nucleic acid, and protein content of $R$. stolonifer.

\section{Conclusion}

The present work reported the antifungal properties and mechanism of the essential oils from Litsea ( $L$. cubeba), Melissa (M. officinalis), Palmarosa (C. martini) and Verbena ( $V$. officinalis) and their major active constituents. The $4 \mathrm{EOs}$ and their major active constituents significantly inhibited mycelial growth of $T$. hirsuta and $L$. sulphureus through disrupting plasma membrane integrity, and resulting in leakage of nucleic acid, protein, and soluble sugar. The essential oils of litsea, melissa, palmarosa and verbena and their major compounds have potential as environmental-friendly fungicides.

\section{Declarations}

\section{Ethical approval}


Not applicable.

\section{Consent to participate}

Not applicable.

\section{Consent to publish}

All authors whose names appear on the submission approved the version to be published and agree to be accountable for all aspects of the work in ensuring that questions related to the accuracy or integrity of any part of the work are appropriately investigated and resolved.

\section{Authors Contributions}

Yongjian Xie, Xi Yang, Hui Han, Zhilin Zhang and Dayu Zhang carried out the experimental stages, manuscript preparation, and statistical analysis.

\section{Funding}

This work was supported by Zhejiang A\&F University research fund for financial supports (No. 2012FR087, 2014FR009).

\section{Competing interests}

The authors declare no competing interests.

\section{Availability of data and materials}

Not applicable.

\section{References}

Adams RP (2007) Identification of essential oil components by gascromatography/ quadrupole mass spectroscopy, 4th edn. Allured Publishing Corporation, Carol Stream, IL, pp. 455.

Bakar ES, Hao J, Ashaari Z, Yong ACC (2013) Durability of phenolic resin treated oil palm wood against subterranean termites a white-rot fungus. Int Biodeterior Biodegrad 85:126-

130. https://doi.org/10.1016/j.ibiod.2013.04.019

Benelli G, Govindarajan M, Rajeswary M, Vaseeharan B, Alyahya SA, Alharbi NS, Kadaikunnan S, Khaled JM, Maggi F (2018) Insecticidal activity of camphene, zerumbone and a-humulene from Cheilocostus speciosus rhizome essential oil against the Old-World bollworm, Helicoverpa armigera. Ecotox Environ Safe 148:781-786. https://doi.org/10.1016/j.ecoenv.2017.11.044 
Boulogne I, Petit P, Ozier-Lafontaine H, Desfontaines L, Loranger-Merciris G, (2012) Insecticidal and antifungal chemicals produced by plants: a review. Environ Chem Lett 10:325-

347. https://doi.org/10.1007/s10311-012-0359-1

Chen PS, Chen YH, Yeh TF, Chang ST (2014) Mechanism of decay resistance of heartwood extracts from Acacia confusa against the brown-rot fungus Laetiporus sulphureus. Wood Sci Technol 48:451465. https://doi.org/10.1007/s00226-014-0615-6

Cheng SS, Lin HY, Chang ST (2005) Chemical composition and antifungal activity of essential oils from different tissues of Japanese cedar (Cryptomeria japonica). J Agric Food Chem 53:614-

619. https://doi.org/10.1021/jf0484529

Cheng SS, Liu JY, Hsui YR, Chang ST (2006) Chemical polymorphism and antifungal activity of essential oils from leaves of different provenances of indigenous cinnamon (Cinnamomum osmophloeum). Bioresour Technol 97:306-312. https://doi.org/10.1016/j.biortech.2005.02.030

Cheng SS, Liu JY, Chang EH, Chang ST (2008) Antifungal activity of cinnamaldehyde and eugenol congeners against wood-rot fungi. Bioresour Technol 99:5145-

5149. https://doi.org/10.1016/j.biortech.2007.09.013

Cheng SS, Lin, CY, Gu HJ, Chang ST (2011) Chemical composition and antifungal activities of wood and leaf essential oils from Cunninghamia konishii Hayata. J Wood Chem Technol 31:204-

217. https://doi.org/10.1080/02773813.2010.515049

Cheng SS, Chung MJ, Lin CY, Wang YN, Chang ST (2012) Phytochemicals from Cunninghamia konishii Hayata act as antifungal agents. J Agric Food Chem 60:124-128.

https://doi.org/10.1021/jf2042196

De Martino L, D’Arena G, Minervini MM, Deaglio S, Sinisi NP, Cascavilla N, De Feo V (2011) Active caspase-3 detection to evaluate apoptosis induced by Verbena officinalis essential oil and citral in chronic lymphocytic leukaemia cells. Rev Bras Farmacogn Braz J Pharmacogn 21:869-

873. https://doi.org/10.1590/S0102-695X2011005000082

Gong X, Ren Y (2020) Larvicidal and ovicidal activity of carvacrol, p-cymene, and y-terpinene from Origanum vulgare essential oil against the cotton bollworm, Helicoverpa armigera (Hübner). Environ Sci Pollut R 27:18708-18716. https://doi.org/10.1007/s11356-020-08391-2

Ho CL, Hsu KP, Wang EIC, Lin CY, Su YC (2010) Composition and anti-wood-decay fungal activities of the leaf essential oil of Machilus philippinensis from Taiwan. Nat Prod Commun 5:337-

340. https://doi.org/10.1002/mnfr.200900502

Kakaraparthi PS, Srinivas KVNS, Kumar JK, Kumar AN, Rajput DK, Anubala S (2015) Changes in the essential oil content and composition of palmarosa (Cymbopogon martini) harvested at different stages 
and short intervals in two different seasons. Ind Crops Prod 69:348-

354. https://doi.org/10.1016/j.indcrop.2015.02.020

Kalily E, Hollander A, Korin B, Cymerman I, Yaron S (2016) Mechanisms of resistance to linalool in Salmonella senftenberg and their role in survival on basil. Environ Microbiol 18:3673-

3688. https://doi.org/10.1111/1462-2920.13268

Khalili G, Mazloomifar A, Larijani K, Tehrani MS, Azar PA (2018) Solvent-free microwave extraction of essential oils from Thymus vulgaris L. and Melissa officinalis L. Ind Crops Prod 119:214-

217. https://doi.org/10.1016/j.indcrop.2018.04.021

Kim J, Seo SM, Lee SG, Shin SC, Park IK (2008) Nematicidal activity of plant essential oils and components from coriander (Coriandrum sativum), oriental sweetgum (Liquidambar orientalis), and valerian (Valeriana vallichii) essential oils against pine wood nematode (Bursaphelenchus xylophilus). J Agric Food Chem 56:7316-7320. https://doi.org/10.1021/jf800780f

Kittler J, Krüger H, Lohwasser U, Ulrich D, Zeiger B, Schütze W, Böttcher C, Gudi G, Kästner U, Marthe F (2018a) Evaluation of 28 balm and lemon balm (Melissa officinalis) accessions for content and composition of essential oil and content of rosmarinic acid. Genet Resour Crop Evol 65:745757. https://doi.org/10.1007/s10722-017-0568-3

Kittler J, Krüger H, Ulrich D, Zeiger B, Schütze W, Böttcher C, Krähmer A, Gudi G, Kästner U, Heuberger H, Marthe $\mathrm{F}(2018 \mathrm{~b})$ Content and composition of essential oil and content of rosmarinic acid in lemon balm and balm genotypes (Melissa officinalis). Genet Resour Crop Evol 65: 1517-

1527. https://doi.org/10.1007/s10722-018-0635-4

Komala VV, Ratnavathi CV, Kumar BSV, Das IK (2012) Inhibition of aflatoxin $\mathrm{B}_{1}$ production by an antifungal component, eugenol in stored sorghum grains. Food Control 26:139-

146. https://doi.org/10.1016/j.foodcont.2012.01.013

Lee YS, Kim J, Shin SC, Lee SG, Park IK (2008) Antifungal activity of Myrtaceae essential oils and their components against three phytopathogenic fungi. Flavour Frag J 23:23-

28. https://doi.org/10.1002/ffj.1850

Li W, Yuan S, Sun J, Li Q, Jiang W, Cao J (2018) Ethyl p-coumarate exerts antifungal activity in vitro and in vivo against fruit Alternaria alternata via membrane targeted mechanism. Int J Food Microbiol 278:2635. https://doi.org/10.1016/j.ijfoodmicro.2018.04.024

Lima JKA, Albuquerque ELD, Santos ACC, Oliveira AP, Araújo APA, Blank AF, Arrigoni-Blank MF, Alves PB, Santos DA, Bacci L (2013) Biotoxicity of some plant essential oils against the termite Nasutitermes corniger (Isoptera: Termitidae). Ind Crops Prod 47:246-

251. https://doi.org/10.1016/j.indcrop.2013.03.018 
Liu TT, Wu HB, Wu HB, Zhang J (2019) Wormwood (Artemisia absinthium L.) as a promising nematicidal and antifungal agent: Chemical composition, comparison of extraction techniques and bioassay-guided isolation. Ind Crops Prod 133:295-303. https://doi.org/10.1016/j.indcrop.2019.03.039

Matan N, Nisoa M, Matan N, Aewsiri T (2014) Effect of cold atmospheric plasma on antifungal activities of clove oil and eugenol against molds on areca palm (Areca catechu) leaf sheath. Int Biodeter Biodegr 86:196-201. https://doi.org/10.1016/j.ibiod.2013.08.025

Park IK, Kim J, Lee SG, Shin SC (2007) Nematicidal activity of plant essential oils and components from ajowan (Trachyspermum ammi), allspice (Pimenta dioica) and litsea (Litsea cubeba) essential oils against pine wood nematode (Bursaphelenchus xylophilus). J Nematol 39:275-279.

Pouyanfar E, Hadian J, Akbarzade M, Hatami M, Kanani MR, Ghorbanpour M (2018) Analysis of phytochemical and morphological variability in different wildand agro-ecotypic populations of Melissa officinalis L. growing in northern habitats of Iran. Ind Crops Prod 112:262-

273. https://doi.org/10.1016/j.indcrop.2017.12.008

Rehman S, Latief R, Bhat KA, Khuroo MA, Shawl AS, Chandra S (2017) Comparative analysis of the aroma chemicals of Melissa officinalis using hydrodistillation and HS-SPME techniques. Arab J Chem 10:S2485-S2490. https://doi.org/10.1016/j.arabjc.2013.09.015

Salem MZM, Zidan YE, Mansour MMA, El-Hadidi NMN, Abo-Elgat WAA (2016) Antifungal activities of two essential oils used in the treatment of three commercial woods deteriorated by five common mold fungi. Int Biodeter Biodegr 106:88-96. https://doi.org/10.1016/j.ibiod.2015.10.010

Seo SM. Kim J, Lee SG, Shin CH, Shin SC, Park IK (2009) Fumigant antitermitic activity of plant essential oils and components from Ajowan (Trachyspermum ammi), Allspice (Pimenta dioica), Caraway (Carum carvi), Dill (Anethum graveolens), Geranium (Pelargonium graveolens), and Litsea (Litsea cubeba) oils against Japanese Termite (Reticulitermes speratus Kolbe). J Agric Food Chem 57:65966602. https://doi.org/10.1021/jf9015416

Shao X, Cheng S, Wang H, Yu D, Mungai C (2013) The possible mechanism of antifungal action of tea tree oil on Botrytis cinerea. J Appl Microbiol 114: 1642-1649. https://doi.org/10.1111/jam.12193

Si L, Chen Y, Han X, Zhan Z, Tian S, Cui Q, Wang Y (2012) Chemical composition of essential oils of Litsea cubeba harvested from its distribution areas in China. Molecules 17:7057-

7066. https://doi.org/10.3390/molecules 17067057

Smith PK, Krohn RI, Hermanson GT, Mallia AK, Gartner FH, Provenzano MD, Fujimoto EK, Goeke BJ, Olson BJ, Klenk DC (1985) Measurement of protein using bicinchoninic acid. Anal Biochem 150:7685. https://doi.org/10.1016/0003-2697(85)90442-7 
Singh G, Maurya S, Catalan C, Lampasona MP (2004) Chemical constituents, antifungal and antioxidative effects of ajwain essential oil and its acetone extract. J Agric Food Chem 52:32923296. https://doi.org/10.1021/jf035211c

Souza DP, Pimentel RBQ, Santos AS, Albuquerque PM, Fernandes AV, Junior SD, Oliveira JTA, Ramos MV, Rathinasabapathi B, Goncalves JFC (2020) Fungicidal properties and insights on the mechanisms of the action of volatile oils from Amazonian Aniba trees. Ind Crops Prod

143:111914. https://doi.org/10.1016/j.indcrop.2019.111914

Tak JH, Isman MB (2017) Penetration-enhancement underlies synergy of plant essential oil terpenoids as insecticides in the cabbage looper, Trichop/usia ni. Sci Rep 7:42432. https://doi.org/10.1038/srep42432

Tian J, Wang Y, Zeng H, Li Z, Zhang P, Tessema A, Peng X (2015) Efficacy and possible mechanisms of perillaldehyde in control of Aspergillus niger causing grape decay. Int J Food Microbiol 202:27-

34. https://doi.org/10.1016/j.ijfoodmicro.2015.02.022

Wang SY, Chen PF, Chang ST (2005) Antifungal activities of essential oils and their constituents from indigenous cinnamon (Cinnamomum osmophloeum) leaves against wood decay fungi. Bioresour Technol 96:813-818. https://doi.org/10.1016/j.biortech.2004.07.010

Wu CC, Wu CL, Huang SL, Chang HT (2012) Antifungal activity of Liriodenine from Michelia formosana heartwood against wood-rotting fungi. Wood Sci Technol 46:737-747. https://doi.org/10.1007/s00226011-0428-9

Xie Y, Huang Q, Yang F, Lei C (2012) Chemical variation in essential oil of Cryptomeria fortunei from various areas of China. Ind Crops Prod 36:308-312. https://doi.org/10.1016/j.indcrop.2011.10.023

Xie Y, Wang K, Huang Q, Lei C (2014) Evaluation toxicity of monoterpenes to subterranean termite, Reticulitermes chinensis Snyder. Ind Crops Prod 53:163-

166. https://doi.org/10.1016/j.indcrop.2013.12.021

Xie Y, Yang Z, Cao D, Rong F, Ding H, Zhang D (2015) Antitermitic and antifungal activities of eugenol and its congeners from the flower buds of Syzgium aromaticum (Clove). Ind Crops Prod 77:780786. https://doi.org/10.1016/j.indcrop.2015.09.044

Xie YJ, Wang ZJ, Huang QQ, Zhang DY(2017a) Antifungal activity of several essential oils and major components against wood-rot fungi. Ind Crops Prod 108:278-

285. https://doi.org/10.1016/j.indcrop.2017.06.041

Xie YJ, Huang QQ, Wang ZJ, Cao HY, Zhang DY (2017b) Structure-activity relationships of cinnamaldehyde and eugenol derivatives against plant pathogenic fungi. Ind Crops Prod 97:388394. https://doi.org/10.1016/j.indcrop.2016.12.043 
Yan J, Wu H, Shi F, Wang H, Chen K, Feng J, Jia W (2020) Antifungal activity screening for mint and thyme essential oils against Rhizopus stolonifer and their application in postharvest preservation of strawberry and peach fruits. J Appl Microbiol 130:1993-2007. https://doi.org/10.1111/jam.14932

Yun DG, Lee DG (2017) Silymarin exerts antifungal effects via membrane targeted mode of action by increasing permeability and inducing oxidative stress. Biochim Biophys Acta Biomembr 1859:467474. https://doi.org/10.1016/j.bbamem.2017.01.009

Zhang ZL, Yang T, Mi N, Wang Y, Li GY, Wang LH, Xie YJ (2016a) Antifungal activity of monoterpenes against wood white-rot fungi. Int Biodeter Biodegr 106:157-

160. https://doi.org/10.1016/j.ibiod.2015.10.018

Zhang Y, Liu X, Wang Y, Jiang P, Quek S (2016b) Antibacterial activity and mechanism of cinnamon essential oil against Escherichia coli and Staphylococcus aureus. Food Control 59:282289. https://doi.org/10.1016/j.foodcont.2015.05.032

Zhou D, Wang Z, Li M, Xing M, Xian T, Tu K (2017) Carvacrol and eugenol effectively inhibit Rhizopus stolonifer and control postharvest soft rot decay in peaches. J Appl Microbiol 124:166178. https://doi.org/10.1111/jam.13612

\section{Figures}



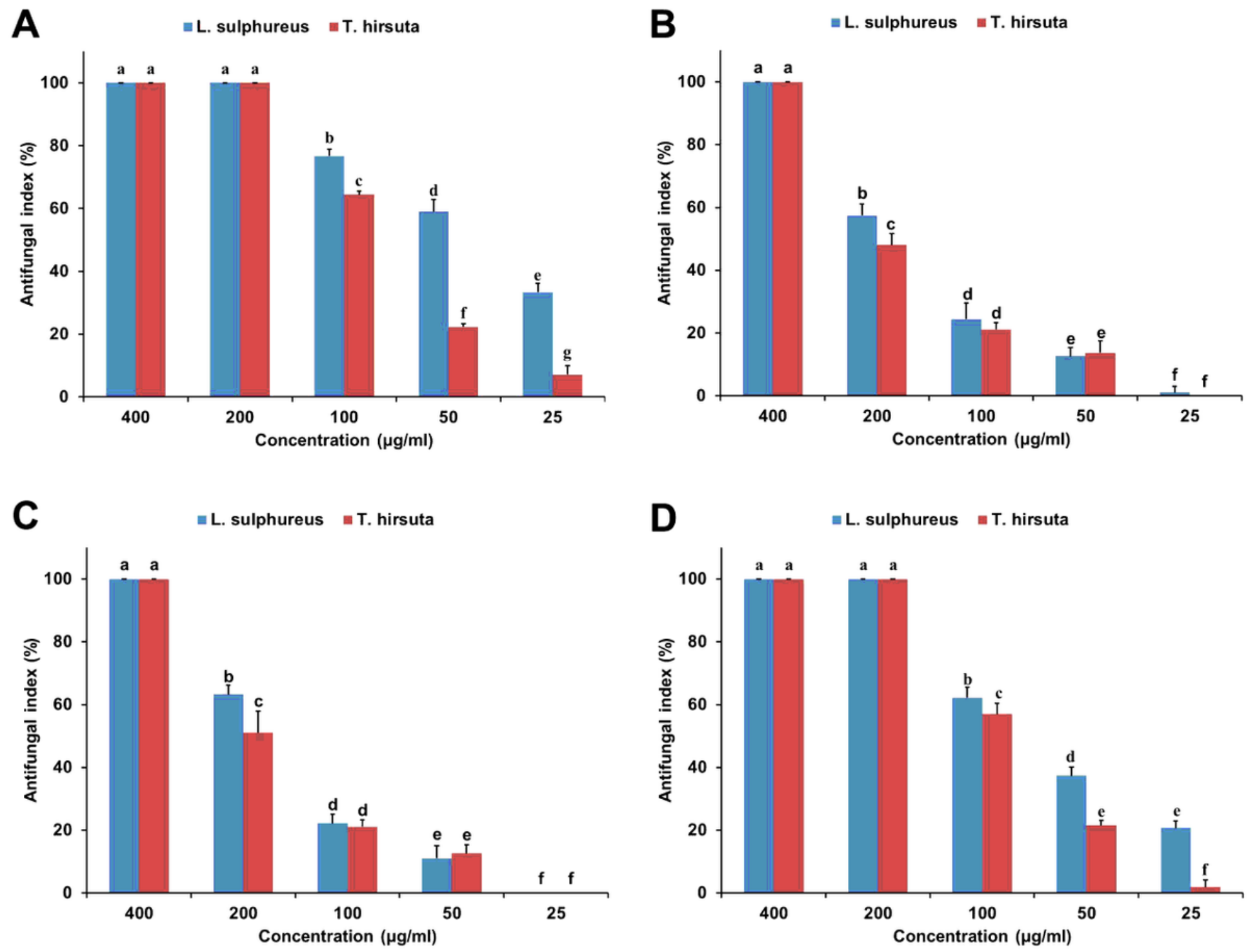

Figure 1

Antifungal activity of the selected essential oils (A: litsea; B: melissa; C: palmarosa; D: verbena) against wood-rot fungus $T$. hirsuta and L. sulphureus. Each experiment was performed $\times 3$ and the data averaged $(n=3)$. Numbers followed by different letters $(a-g)$ are significantly different at level of $P<0.05$ according to Duncan's test. 

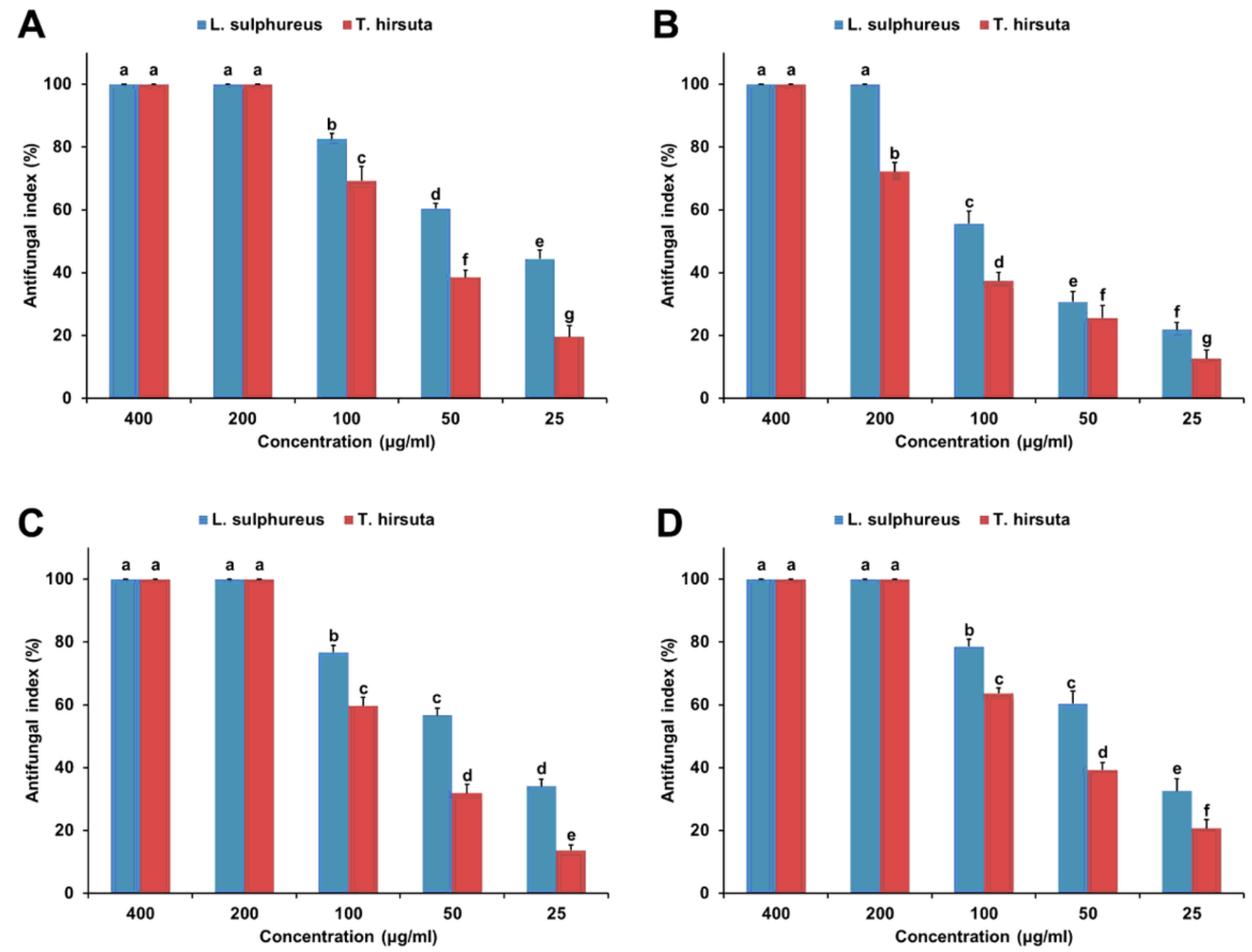

Figure 2

Antifungal activity of major component of the selected essential oils (A: geranial; B: geraniol; C: neral; D: citral) against wood-rot fungus T. hirsuta and L. sulphureus. Each experiment was performed $\times 3$ and the data averaged $(n=3)$. Numbers followed by different letters $(a-g)$ are significantly different at level of $P<$ 0.05 according to Duncan's test. 


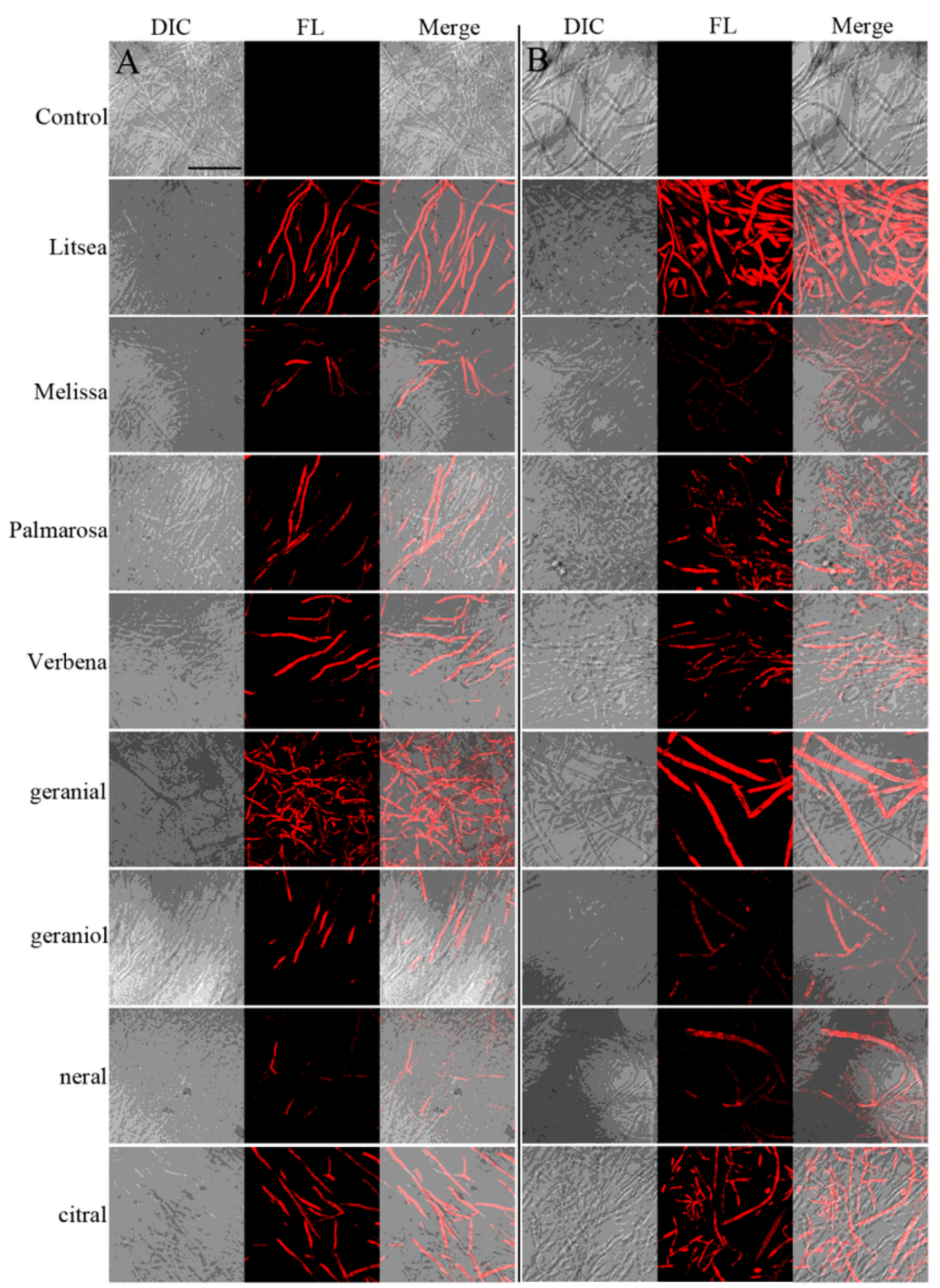

\section{Figure 3}

Confocal laser scanning microscopy images of T. hirsuta (A) and L. sulphureus (B) mycelium membrane integrity exposed to 4 essential oils and their major components at $1 \mu \mathrm{l} / \mathrm{ml}$. DIC: differential interference contrast images without fluorescence. FL: red fluorescence images with propidiumiodide (PI) combined with nucleic acid. Bar $=50.0 \mu \mathrm{m}$. 

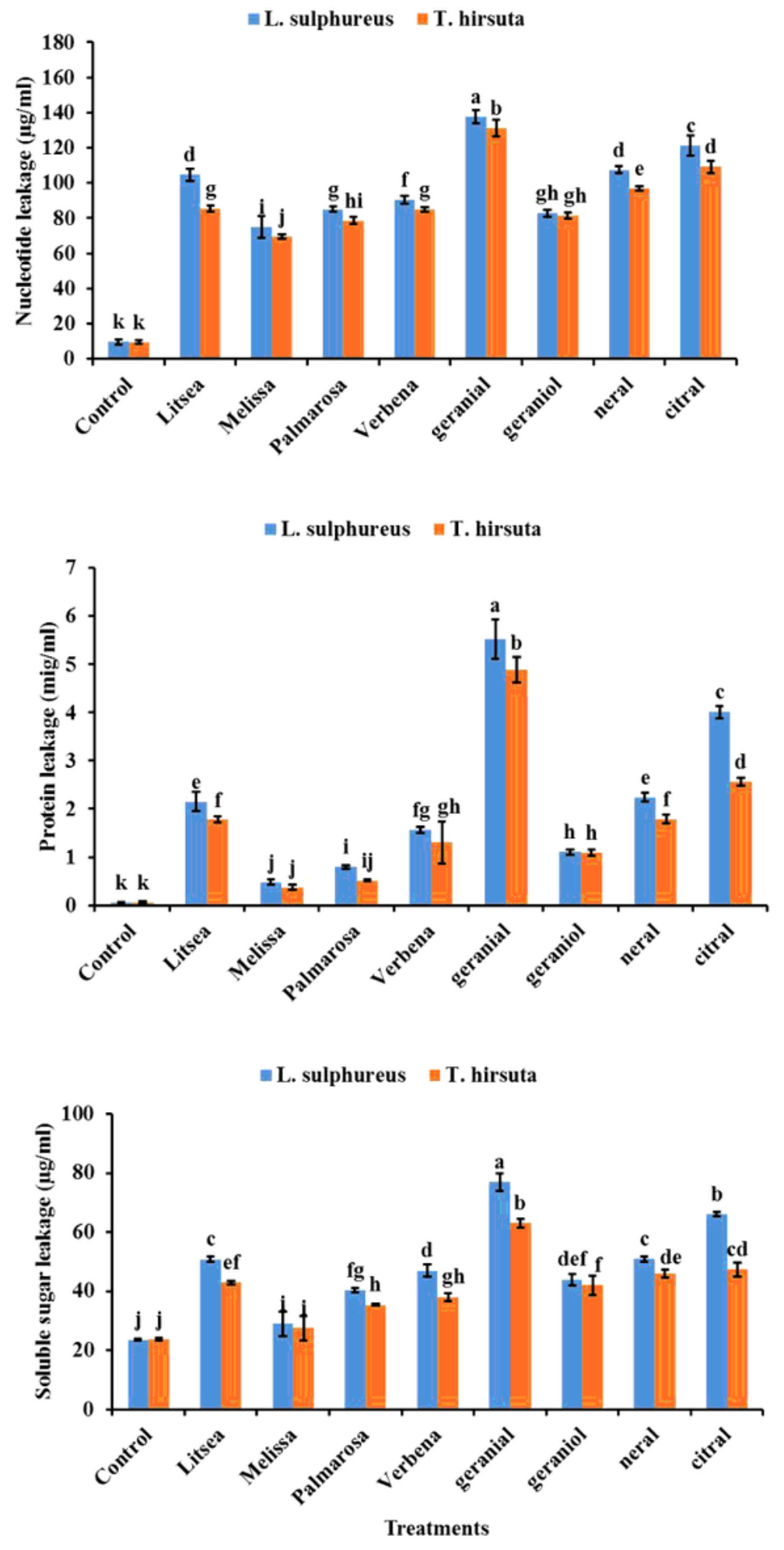

Figure 4

Effects of 4 essential oils and their major components at $1 \mu \mathrm{l} / \mathrm{ml}$ on leakage of nucleic acid $(A)$, protein (B), and soluble sugar (C) of T. hirsuta and L. sulphureus mycelium. Each value is the mean for three replicates, and means with different letters are significantly different based on Duncan's $(P<0.05)$. 